\title{
Pentingnya Menerapkan K3 Untuk Menghindari Penyakit Akibat Kerja \\ Pada Perawat
}

\section{Christin Butar Butar}

christinbutarbutar19@gmail.com

\section{LATAR BELAKANG}

Rumah sakit adalah tempat penyediaan layanan Kesehatan untuk masyarakat. Rumah sakit merupakan salah satu tempat kerja yang berpotensi menimbulkan bahaya dan harus menjamin kesehatan dan keselamatan baik terhadap pasien, penyediaan layanan atau pekerja maupun masyarakat sekitar dari berbagai potensi bahaya di Rumah Sakit. Oleh karena itu, Rumah Sakit dituntut untuk melaksanakan Upaya Kesehatan dan Keselamatan Kerja (K3) yang dilaksanakan secara terintegrasi dan menyeluruh sehingga risiko terjadinya. Penyakit Akibat Kerja (PAK) dan Kecelakaan Akibat Kerja (KAK) di Rumah Sakit dapat dihindari. Penyakit akibat kerja di rumah sakit dapat menyerang semua tenaga kerja baik medis maupun non medis.

Pemerintah melakukan berbagai upaya untuk mengatasi kecelakaan kerja di rumah sakit, salah satunya dengan dikeluarkannya Undang-Undang Nomor 23 Tahun 1992 dan Undang-Undang Nomor 36 Tahun 2009 tentang penerapan Kesehatan dan Keselamatan Kerja di rumah sakit. Kecelakaan kerja pada perawat dianggap sebagai suatu masalah serius karena mengancam kesehatan dan kesejahteraan pasien dan petugas Kesehatan secara global (Maria, 2015). Kecelakaan tersebut yang pada akhirnya dapat mempengaruhi produktivitas kerja perawat. Produktivitas kerja yang rendah pada akhirnya berdampak terhadap pelayanan kesehatan yang diberikan oleh rumah sakit.

Kesehatan dan Keselamatan Kerja (K3) adalah upaya untuk memberikan jaminan keselamatan dan meningkatkan derajat kesehatan pekerja dengan cara pencegahan kecelakaan dan penyakit akibat kerja (PAK), pengendalian bahaya di tempat kerja, promosi kesehatan, pengobatan, dan rehabilitasi. Keselamatan dan kesehatan kerja adalah kegiatan yang dirancang untuk menjamin keselamatan dan kesehatan di tempat kerja. Perawat berisiko terhadap kecelakaan dan penyakit akibat pekerjaan. 


\section{METODE}

Metode yang digunakan dalam kajian Perumusan diagnosa keperawatan dalam mencapai asuhan keperawatan ini menggunakan metode pengumpulan data dengan menggunakan literature review berdasarkan teks buku,buku referensi,jurnal (10 tahun terakhir) dengan menganalisis dan membaca setiap sumber literature berkenaan dengan topik materi yang sedang dibahas untuk mendapatkan berbagai informasi yang lengkap dan akurat dengan cara menyimpulkannya dari literature review yang ada.

\section{HASIL}

Penyakit karena kerja adalah seuatu kendala pada tingkat keamanan dalam kerja, dalam perihal ini memerlukan usaha pencegahan, baik untuk keselamatan ataupun kesehatan beberapa pekerja yang berada di lingkungan rumah sakit. Penyakit karena kerja atau terkait dengan pekerjaan bisa dikarenakan oleh pemajanan di lingkungan kerja dengan terus menerus setiap hari. Untuk menghadapi perihal ini, maka langkah awal yang terpenting ialah pengenalan/identifikasi bahaya yang dapat muncul serta dievaluasi, lalu dikerjakan usaha pengendalian lewat cara melihat serta mengenal (walk through inspections).

Perawat termasuk kelompok tenaga kesehatan yang masuk dalam kelompok rentan tertular (vulnerable people) serta menjadi kelompok berisiko atau rawan tertular karena setiap hari perawat kontak langsung dengan pasien dalam waktu cukup lama, kurang lebih 6-8 jam per hari, sehingga selalu terpajan mikroorganisme penyebab penyakit. Bahaya biologi dapat disebabkan karena terdapat organisme penyebab penyakit pada tempat kerja atau zat yang dihasilkan dari mikroorganisme yang mengancam kesehatan manusia.

Kapasitas kerja, beban kerja dan lingkungan kerja merupakan tiga komponen utama dalam kesehatan kerja, dimana hubungan interaktif dan serasi antara ketiga komponen tersebut akan menghasilkan kesehatan kerja yang baik dan optimal. Kapasitas kerja yang baik seperti status kesehatan kerja dan gizi kerja yang baik serta kemampuan fisik yang prima diperlukan agar seorang pekerja dapat melakukan pekerjaannya dengan baik. Kondisi atau kesebatan pekerja sebagai model awal seseorang untuk melakukan pekerjaan harus pula mendapat perhatian. Kondisi awal seseorang untuk bekerja dapat dipengaruhi oleh kondisi tempat kerja, gizi dan lain-lain. Akibat beban kerja yang terlalu berat atau kemampuan fisik yang terlalu lemah dapat mengakibatkan seorang pekerja menderita gangguan atau penyakit akibat kerja 


\section{PEMBAHASAN}

Penyakit Akibat Kerja (PAK) merupakan penyakit yang artifisial atau man made disease hal ini merupakan problem bagi para pekerja di berbagai sektor. Sebagaian orang menyadari bahwa penyakit yang diderita besar kemunginan karena pekerjaannya, tetapi banyak yang tidak menyadari bahwa penyakit yang diderita besar kemungkinan karena pekerjaannya tetapi banyak yang tidak menyadari bahwa pekerjaan yang ditekuninya sehari - hari sebagai penyebab penyakit tertentu.

Banyak definisi tentang penyakit akibat kerja yang semuanya terkait dengan alat kerja dan pekerjaan. Beberapa di antaranya antara lain, "An occupational disease may be defined simply as one that is caused or made worse, by exposure at work" (Cherry, 1999). Di sini menggambarkan bahwa secara sederhana sesuatu yang disebabkan atau diperburuk oleh pejanan di tempat kerja. Atau " An occupational disease is health problem caused by exposure to workplace hazard" (Workplace Safety and Insurance Board, 2005) sedangkan dari definisi kedua tersebut, penyakit akibat kerja adalah suatu masalah kesehatan yang disebabkan oleh pejanan di tempat kerja. Penyakit akibat kerja telah ada seusia peradaban manusia. Namun, publikasi secara terbuka berkaitan dengan penyakit akibat kerja baru ditulis oleh Bernardino Ramazzini (1633 - 1714), seorang dokter keluarga D’Este di Modena.

Penyakit akibat kerja merupakan manifestasi dari kesehatan kerja, atau kondisi kesehatan dari tenaga kerja atau pekerja. Kesehatan kerja meliputi berbagai upaya penyerasian antara pekerja dengan pekerjaan dengan pekerjaan dan lingkungan kerjanya baik fisik maupun psikis dalam hal cara/metode kerja, proses, kerja dan kondisi yang bertujuan untuk :

1. Memelihara dan meningkatkan derajat kesehatan kerja masyarakat pekerja di semua lapangan kerja setinggi - tingginya baik fisik, mental maupun kesejahteraan sosialnya

2. Mencegah timbulnya gangguan kesehatan pada masyarakat pekerja yang diakibatkan oleh keadaan/kondisi lingkungan kerjanya

3. Memberikan pekerjaan dan perlindungan bagi pekerja di dalam pekerjaanya dari kemungkinan bahaya yang disebabkan oleh factor - factor yang membahayakan kesehatan.

4. Menempatlkan dan memilihara pekerja di suatu lingkungan pekerjaan yang sesuai dengan kemampuan fisik dan psikis pekerjaannya. 
Hal yang perlu dipertimbangkan dalam mengidentifikasi, menganalisa serta mengatasi penyakit akibat kerja adalah kepasitas kerja, beban kerja dan lingkungan kerja. Ketiganya memberikan andil yang sangat besar bagi timbulnya penyakit akibat kerja. Kapasitas kerja, beban kerja dan lingkungan kerja merupakan tiga komponen utama dalam kesehatan kerja, dimana hubungan interaktif dan serasi antara ketiga komponen tersebut akan menghasilkan kesehatan kerja yang baik dan optimal. Kapasitas kerja yang baik seperti status kesehatan kerja dan gizi kerja yang baik serta kemampuan fisik yang prima diperlukan agar seorang pekerja dapat melakukan pekerjaannya dengan baik. Kondisi atau kesebatan pekerja sebagai model awal seseorang untuk melakukan pekerjaan harus pula mendapat perhatian. Kondisi awal seseorang untuk bekerja dapat dipengaruhi oleh kondisi tempat kerja, gizi dan lain-lain. Akibat beban kerja yang terlalu berat atau kemampuan fisik yang terlalu lemah dapat mengakibatkan seorang pekerja menderita gangguan atau penyakit akibat kerja

Dalam perihal ini perlu mendapatkan perhatian, sebab seseorang yang bekerja bila mengalami kecelakaan atau penyakit karena kerja tidak hanya punya pengaruh pada diri sendiri, tapi ikut produktifitas kerja mengalami penurunan dalam pemberian service kesehatan yang optimal pada pasien. Kemungkinan petugas rumah sakit pada gangguan kesehatan serta kecelakaan kerja biasanya dikarenakan oleh perilaku petugas dalam kepatuhan melakukan tiap-tiap mekanisme pada kewaspadaan. Faktor-fakor pemicu penyakit akibat kerja dapat dibedakan sebagai berikut:

a. Faktor Fisik, yang meliputi:

- Suara tinggi/bising yang dapat menyebabkan ketulian.

- Temperatur/suhu tinggi yang dapat menyebabkan Hyperpireksi, Milliaria, heat Cramp, Heat Exhaustion, Heart Stroke.

- Radiasi sinar elektromagnetik, pada mata infra merah dapat menyebabkan katarak, ultraviolet menyebabkan konjungtivitis, radioaktif/ alfa/ beta/ gama/ $\mathrm{X}$ menyebabkan gangguan terhadap sel tubuh manusia.

- Tekanan udara tinggi yang dapat menyebabkan Coison Disease.

- Getaran/vibration yang dapat menyebabkan Reynaud's Disease, Gangguan proses metabolisme, Polineurutis. 


\section{b. Faktor Kimia}

- Berasal dari bahan baku, bahan tambahan, hasil antara, hasil samping, hasil (produk), sisa produksi atau bahan buangan yang dapat berbentuk zat padat, cair, gas, uap maupun partikel. Materi ini masuk ke tubuh dapat melalui saluran pernafasan, saluran pencernaan, kulit dan mukosa.

- Efek terhadap tubuh dapat menyebabkan iritasi, alergi, korosif, Asphyxia, keracunan sistemik, kanker, kerusakan/kelainan janin, pneumoconiosis, efek bius (narkose) dan pengaruh genetik

c. Faktor biologi yang dapat berasal dari virus, bakteri, parasit, jamur, serangga, binatang buas, dan lain-lain.

d. Faktor Ergonomi/Fisiologi. Penyebabnya adalah cara kerja, posisi kerja, alat kerja, lingkungan kerja yang salah dan kontruksi salah. $\neg$ Efek terhadap tubuh yaitu dapat menyebabkan kelelahan fisik, nyeri otot, deformitas tulang, perubahan bentuk dan dislokasi

e. Faktor Mental/Psikologi. Penyebabnya yaitu suasana kerja monoton dan tidak nyaman, hubungan kerja kurang baik, upah kerja kurang, terpencil, atau tak sesuai bakat yang mengakibatkan stress.

Risiko utama akibat kerja pada perawat adalah penyakit menular, cedera otot dan tulang, gangguan tidur.

1. Penyakit menular Tenaga perawat kemungkinan melakukan kontak yang berhubungan dengan cairan darah berkuman, cairan tubuh, busa, cairan mulut, cairan urine, kotoran manusia, muntahan dan lainlain sehingga mendapat penularan.

Media penularan :

- Penularan melalui cairan darah

- Penularan melalui udara atau busa

- Penularan melalui kontak tubuh

- Penularan melalui mulut -(berkontak dengan cairan urine dan kotoran manusia) Penyakit menular : Hepatitis B, hepatitis C, AIDS, Flu menular, TBC, SARS, Penyakit kulit biasa, radang infeksi kulitRadang infeksi perut, hepatitis A. 
2. Sakit otot dan tulang Tindakan memindahkan pasien, membalikkan dan menepuknepuk punggung pasien, latihan penyembuhan, dikarenakan sering mengeluarkan tenaga berlebihan, gerakan yang tidak benar atau berulang-ulang, mudah menyebabkan cedera di bagian otot dan tulang, apabila tenaga perawat berusia agak tua, maka akan menambah resiko dan tingkat keseriusan cedera di otot dan tulang.

3. Gangguan tidur Tenaga perawat perlu waktu sepanjang malam atau waktu yang tidak tentu untuk menjaga pasien, sehingga mudah mengalami kondisi tidur pendek, tidur kurang lelap, kesulitan tidur.

Untuk mengantisipasi hal ini, maka Langkah -langkah yang penting adalah pengenalan/ identifikasi bahaya yang bisa timbul dan dievaluasi, kemudian dilakukan pengendalian. Karena itu, untuk mengantisipasi dan mengetahui kemungkinan bahaya di lingkungan kerja ditempuh tiga Langkah utama (WHO, 1997) yakni :

1. Pengenalan lingkungan kerja

Pengenalan lingkungan kerja ini biasanya dilakukan dengan cara melihat dan mengenal (walk throught inspection) dan ini merupakan langkah dasar yang pertama tama dilakukan dalam upaya kesehatan kerja

2. Evaluasi lingkungan kerja

Merupakan tahap penilaian karakteristik dan besarnya potensi potensi bahaya yang mungkin timbul, sehingga bisa untuk menentukan prioritas dalam mengatasi permasalahan.

3. Pengendalian lingkungan kerja

Pengendalian lingkungan kerja dimaksudkan untuk mengurangi atau menghilangkan pemajanan terhadap agen yang berbahaya di lingkungan kerja. Kedua tahapan sebelumnya, penegnalan dan evaluasi, tidak dapat menjamin sebuah lingkungan kerja yang sehat. Jadi hanya dapat dicapai dengan teknologi pengendalian yang memadai untuk mencegah efek kesehatan yang merugikan di kalangan para pekerja 
Penerapan konsep lima tingkatan pencegahan penyakit (five level of prevention disease) pada penyakit akibat kerja, yakni:

a. Peningkatan kesehatan (health promotion). Misalnya: penyuluhan kesehatan dan keselamatan kerja (K3) pendidikan kesehatan, meningkatkan gizi yang baik, pengembangan kepribadian, perusahaan yang sehat dan memadai, rekreasi, lingkungan kerja yang memadai, penyuluhan perkawinan dan pendidikan seksual, konsultasi tentang keturunan dan pemeriksaan kesehatan periodik.

b. Perlindungan khusus (specific protection). Misalnya: imunisasi, hygiene perorangan, sanitasi lingkungan, serta proteksi terhadap bahaya dan kecelakaan kerja dengan menggunakan alat pelindung diri (APD) seperti helm, kacamata kerja, masker, penutup telinga (ear muff dan ear plug) baju tahan panas, sarung tangan, dan sebagainya.

c. Diagnosis (deteksi) dini dan pengobatan segera serta pembatasan titik-titik lemah untuk mencegah terjadinya komplikasi.

d. Membatasi kemungkinan cacat (disability limitation). Misalnya: memeriksa dan mengobati tenaga kerja secara komprehensif, mengobati tenaga kerja secara sempurna dan pendidikan kesehatan.

e. Pemulihan kesehatan (rehabilitation). Misalnya: rehabilitasi dan mempekerjakan kemali para pekerja yang menderita cacat. Sedapat mungkin perusahaan mencoba menempatkan keryawan-karyawan cacat di jabatan yang sesuai.

Selain itu upaya yang dapat dilakukan oleh untuk mencegah PAK adalah sebagai berikut: 1. Menyingkirkan atau mengurangi risiko pada sumbernya, misalnya menggantikan bahan kimia yang berbahaya dengan bahan yang tidak berbahaya.

2. Mengurangi risiko dengan pengaturan mesin atau menggunakan APD.

3. Menetapkan prosedur kerja secara aman untuk mengurangi risiko lebih lanjut.

4. Menyediakan, memakai dan merawat APD 


\section{PENUTUP}

\section{Kesimpulan}

Penyakit Akibat Kerja adalah penyakit yang disebabkan oleh pekerjaan dan lingkungan kerja. Faktor risiko PAK antara lain: Golongan fisik, kimiawi, biologis atau psikososial di tempat kerja. Faktor tersebut di dalam lingkungan kerja merupakan penyebab yang pokok dan menentukan terjadinya penyakit akibat kerja. Faktor lain seperti kerentanan individual juga berperan dalam perkembangan penyakit di antara pekerja yang terpajan.

\section{Saran}

Perawat sebagai tenaga kesehatan yang paling lama kontak dengan pasien harus memahami risikonya dan menerapkan $\mathrm{k} 3$ dengan sebaik-baiknya agar tidak terjadi penyakibat akibat kerja (PAK) dan kecelakaan akibat kerja (KAK). Sebab pelayanan keperawatan memegang kunci dalam upaya penerapan

\section{DAFTAR PUSTAKA}

Anies. 2005. Penyakit Akibat Kerja.Jakarta: PT Elex Median Komputindo.

Ardenny .(2015). Faktor Yang Berhubungan Dengan Kecelakaan Kerja Pada Perawat Di Rumah Sakit Jiwa Tampan Pekan Baru . Jurnal Proteksi Kesehatan, Vol 4(1), 1-6

Iwan M. Ramdan, Abd. Rahman.(2017). Analisis Risiko Kesehatan dan Keselamatan Kerja (K3) pada Perawat. JKP .5(3)

Liza, Salawati. (2015).Penyakit Akibat Kerja Dan Pencegahan . JKS. Fakultas Kedokteran Universitas Syiah Kuala Banda Aceh 
Maria, Silvia., Joko Wiyono., \& Erlisa Candrawati. (2015). Kejadian Kecelakaan Kerja Perawat Berdasarkan Tindakan Tidak Aman. Jurnal Care, 3(2), 9-17.

Novi Ernawati, Hj Ella Nurlelawati. (2017). Faktor-Faktor Yang Berhubungan Dengan Pelaksanaan Penerapan K3 Pada Tenaga Kesehatan Di RSIA Permata Sarana Husada. Jurnal Akademik Keperawatan Husada Karya Jaya, Vol 3(1)

Nur Azizah, Setiawan2, Gerry Silaban.(2018) .Hubungan Antara Pengawasan,Prosedur Kerja dan Kondisi Fisik Dengan Terjadinya Kecelakaan Pada Perawat Di Ruang Inap Sakit Permata Bunga Medan. Jurnal JUMANTIK Vol.3 (2)

Putri, Santoso.\& Endang, P. R. (2018). Pelaksanaan Keselamatan Dan Kesehatan Kerja Terhadap Kejadian Kecelakaan Kerja Perawat Rumah Sakit. Jurnal Endurance, 3(2), 271273.

Salawati, L. (2015). Penyakit Akibat Kerja Dan Pencegahan. Jurnal Kedokteran Syiah Kuala, 15(2), 91-94.

Simamora, R. H. (2017). A strengthening of role of health cadres in BTA-Positive Tuberculosis (TB) case invention through education with module development and video approaches in Medan Padang bulan Comunity Health Center, North Sumatera Indonesia. International Journal of Applied Engineering Research, 12(20), 10026-10035.

Simamora, R. H., \& Saragih, E. (2019). Penyuluhan kesehatan terhadap masyarakat: Perawatan penderita asam urat dengan media audiovisual. JPPM (Jurnal Pendidikan dan Pemberdayaan Masyarakat), 6(1), 24-31.

Widiwati Rinjani Octavia, A.T Diana Nerawati, Ernita S. (2018).Penerapan Pelayanan Kesehatan Dan Keselamatan Kerja Pada Perawat IGD Rumah Sakit Umum DR. Wahidin Sudiro Husada Mojokerto. Gema Kesehatan Lingkungan,Vol 16(1) 